\title{
IAMJ
}

INTERNATIONAL

AYURVEDIC

MEDICAL JOURNAL

\section{A CONCEPTUAL STUDY ON THE EFFECT OF GUGGULU BASED GANDHAMLIYA YASHADA KSHARA SUTRA IN SHALYAJA NADI VRANA}

\author{
Keerthi Kumari B. $\mathbf{R}^{1}$, Shilpa P. $\mathbf{N}^{2}$ \\ ${ }^{1}$ MS Scholar, Dept of Shalya tantra, Government Ayurvedic Medical College, Bengaluru, Karnataka, India \\ ${ }^{2}$ MS (Ayu), Associate Professor, Dept of Shalya Tantra, Government Ayurvedic Medical College, Bengaluru, Karnataka, \\ India
}

Corresponding Author: keerthibr02@gmail.com

https://doi.org/10.46607/iamj1209022021

(Published online: February 2021)

Open Access

(C) International Ayurvedic Medical Journal, India 2021

Article Received: 08/01/2021 - Peer Reviewed: 24/01/2021 - Accepted for Publication: 31/01/2021

\section{Check for updates}

\section{ABSTRACT}

Kshara Sutra is a unique para surgical procedure mentioned in Ayurveda. Kshara Sutra is defined as a medicated thread coated with herbal alkaline drugs. Kshara Sutra prayoga is mentioned by Acharya Sushrutha in the management of Shalyaja Nadi Vrana. Acharya Sushrutha has explained Shalyaja Nadi Vrana as a complication of Vrana Shopha. Shalyaja Nadi Vrana is manifested due to presence of Bala (hairs) and puya (pus) in Twagadi dhatus. Pilonidal Sinus can be correlated with Shalyaja Nadi Vrana as they have same clinical features. Pilonidal Sinus is managed by radical excision of tract or $\mathrm{Z}$ plasty or by using rhomboidal flap of skin. Even by all these management in contemporary science expected results is not seen. To overcome the complications like recurrence, hospitalization and long-term post-op dressing, a Kshara Sutra can be used as a better treatment modality as it minimizes many of the complications. Many established herbal Kshara Sutras are available in market. Guggulu based Gandhamliya yashada kshara sutra has Gandhamliya yashada as Kshara which is a Rasaushadi. Gandhamliya Yashada Kshara has properties which will be helpful in lysis of tissues, reduces the discharge and also helps in wound healing in Shalyaja Nadi Vrana. So, this study is taken up to explore the combined effect of a herbo mineral Guggulu based Gandhamliya yashada kshara sutra in Shalyaja Nadi Vrana.

Keywords: Shalyaja Nadi Vrana, Gandhamliya Yashada Kshara Sutra, Pilonidal Sinus. 


\section{INTRODUCTION}

Shalyaja Nadi Vrana i.e. Pilonidal Sinus has become a challenge to most of the surgeons due to its recurrence. This is commonly found in drivers and in sedentary workers. Due to constant sitting there is exertion on post anal region where the pits pull the hair inside the body to cause pilonidal Sinus.

Shalyaja Nadi Vrana is a type of Nadi Vrana explained by Acharya Sushrutha as a complication of Vrana Shopha. It persists due to presence of Bala and Puya entering into twagadi dhatus, eventually leading into a Nadi Vrana.

Shalyaja Nadi vrana is identified by the presence of Shalya (foreign body) which is agantuja and gets lodged within the body and is invisible. Due to which there will be haemangenous frothy discharge, sometimes hot in nature. The discharge varies from minimum to maximum and is associated with mild to moderate pain. Here, the Gati (movement) of the Shalya is very slow, as the foreign body gets lodged in the tissue rather than floating, it is difficult to remove hairs. So, the sinus will heal slowly. Shalyaja Nadi vrana is Kashta sadhya.

Acharya Sushrutha has advised the use of Eshani i.e probe for local examination. With the help of a probe direction of tract and its length can be assessed easily. It is also used for probing ${ }^{(1)}$. The line of treatment of Nadi Vrana is excision of the tract along with its linings. The word "Shastrena utpathya karmavit" indicates the exploration of the tract and its excision. After the surgical procedure, further management is similar to the management of Vrana. Nadi Vrana is also indicated among Chedya, Bhedya and Aharana yogya vyadhis as extraction of foreign body is required in Nadi Vrana. Acharya Sushrutha has indicated the use of Kshara sutra in Nadi Vrana in the patients who are emaciated, timid and located at the Marma sthanas ${ }^{(2)}$. The contemporary science describes a similar condition known as Pilonidal Sinus. A Pilonidal Sinus is a blind tract extending from surface of skin into deeper tissues lined by unhealthy granulation tissue ${ }^{(3)}$. Broken hairs tend to collect in natal cleft eventually penetrates into skin to form Pilonidal Sinus.
Incidence of disease is about 26 lakh per population typically seen in hirsute male than in female in ratio of 6:1 ${ }^{(4)}$. The most common surgical technique used for this disorder includes radical excision, evacuation and curettage, closure by $\mathrm{Z}$ plasty, rhomboidal flap surgery, excision and flip skin grafting which requires anesthesia, hospitalization and long-term post-op dressing ${ }^{(5)}$. In surgeries like Z- plasty and rhomboidal flap there is altering of anatomical structure, ramification occurs, scar tissue will be formed. This again leads to recurrence which is $20 \%$ even after adequate incision and proper dressing. There will also be a chance of developing secondary infection of the wound.

Acharya Sushrutha has advocated a very unique, minimally invasive technique i.e. Kshara Sutra in the management of Shalyaja Nadi Vrana. Kshara Sutra is minimally invasive as it does not alter any anatomical structure. No hospitalization is required, and it is a simple OPD based procedure. Available Kshara sutras in market are herbal. Collection of the drug is difficult as it should be collected in a particular time. Snuhi ksheera which is used as base should be collected only in Adana kala. To overcome this Guggulu is used as base which can be collected and stored for a long time. Instead of Apmarga kshara, Gandhamliya Yashada is used as Rasaushadi will be very potent even in small dose when compared to herbal drug. It cuts the tracts, helpful in lysis of tissues, reduces the discharge and also helps in wound healing, removes the Shalya while changing the Kshara sutra. By considering all these factors Guggulu based Gandhamliya Yashada Kshara sutra has been taken up for the study in Shalyaja Nadi Vrana which is a Kashta sadya vyadhi.

Preparation of Gandhamliya Yashada Kshara Sutra Materials required

a. Shodita Guggulu

b. Gandhamliya yashada Kshara

Shodhana - Yashada is taken in an iron pan, heated till it melts and poured into a container having Sudha jala. This procedure is repeated for 7 times ${ }^{(6)}$. 
Yashada churna - Shoditha yashada is taken in an iron pan, heated till it attains molten state. Small amount of apamarga pancanga is added and heated, till yashada attains powder form. Heat is stopped, Yashada churna is allowed to cool ${ }^{(7)}$.

Gandhamliya Yashada - Yashada churna is taken in a Loha paatra. Gandhamla jala is added till Yashada dips. Solution is filtered. Obtained solution is subjected to heat on mild fire till white colored Gandhamliya yashada kshara is obtained ${ }^{(8)}$.

\section{c. Haridra}

Method of Preparation of Guggulu Based Gandhamliya Yashada Kshara Sutra

Kshara Sutra will be prepared by using Barbor's surgical linen thread No. 20. Initially thread will be coated with 11 coatings of Guggulu and dried after each coating. 7 coatings of Guggulu and Gandhamliya Yashada Kshara is applied consequently and dried after each coating. Following 3 coatings of Guggulu and Haridra churna is applied and dried. Thus, prepared Kshara Sutra are exposed to UV rays and stored in an airtight container.

\section{Procedure of Application of Kshara Sutra}

In the procedure of Kshara Sutra application, patient is made to lie in prone position. Under aseptic measures probing will be done into the tract till resistance is felt, following which an artificial opening is made at the site. Thus, converting a sinus tract into a fistula. Primary threading is done. After 2 days primary thread is replaced by Kshara Sutra in railroad method and ligated adequately tight. On every $7^{\text {th }}$ day Kshara Sutra change is done and hairs are removed which are adhered to Kshara sutra. Length of Tract is measured in every sitting of Kshara Sutra change. Observation should be made till complete cutting and healing of tract.

\section{DISCUSSION}

\section{Properties of Guggulu Based Gandhamliya Yashada} Kshara Sutra

- Guggulu used in Kshara sutra will be having Sukshma, Tridoshagna, Lekhana, Vedana sthapana and Shodhana guna, it also acts as a good binding agent ${ }^{(9)}$. Collected Guggulu niryasa can be stored and used for a long time.

- Gandhamliya Yashada Kshara is having Puyaghna, Vrana samsrava shamana, Sankocakara guna and is Sreshta kshara karma Kara param ${ }^{(10)}$. These properties will be beneficial in treating Shalyaja Nadi Vrana as there is Vedana, Puya srava and Vrana.

- Gandhamliya Yashada is Zinc Sulphate. Zinc sulphate is used as a dietary supplement and also used in treating zinc deficiency. Zinc is especially beneficial for inflammatory skin condition. So, Zinc sulphate is beneficial in treating the wound condition.

- Haridra is having Krimighna properties. The anti-bacterial effect of turmeric helps in avoiding secondary infection of the wound.

The drugs used in preparation of Kshara Sutra are easily available. A surgeon can prepare it easily and can use it in the clinical practice. The properties of individual drug have been explained and the combined effect of drugs in Kshara Sutra helps in debridement and lysis of tissues. Recurrence of the disease is one of the main complications of pilonidal sinus, this herbo-mineral Kshara sutra can help in fast healing and cutting of the tract by destroying the residual glands in epithelium. In every consecutive changing of Kshara Sutra, Bala which is a Shalya which would be adhered to Kshara Sutra is removed. So, the causative factor is treated. Post op complication like secondary infection of the wound doesn't occur. Long term post op dressing is not required. With minimal invasion maximum benefits is obtained by this Kshara Sutra technique.

\section{CONCLUSION}

Since Kshara Sutra is considered to be simple, safe and minimally invasive Para-surgical procedure it can be used in Shalyaja Nadi Vrana. Shalyaja Nadi Vrana has Bala as Shalya along with Vrana, Srava and Vedana. Gandhamliya yashada has Puyaghna, Vrana samsrava hara properties. Yashada helps in Vrana shodana, Ropana and Sankochakara property of Yashada helps in closing of the tract. By considering 
all these factors, Gandhamliya Yashada Kshara sutra can be taken up in Shalyaja Nadi vrana for the pur- pose of study and results can be evaluated.

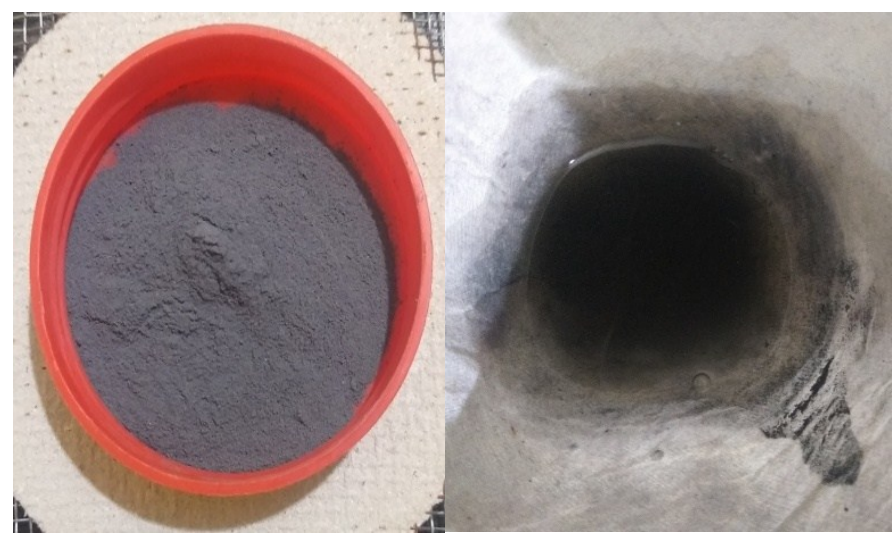

Fig 1: Yashada Churna

Fig 2: Filtration of Gandhamliya

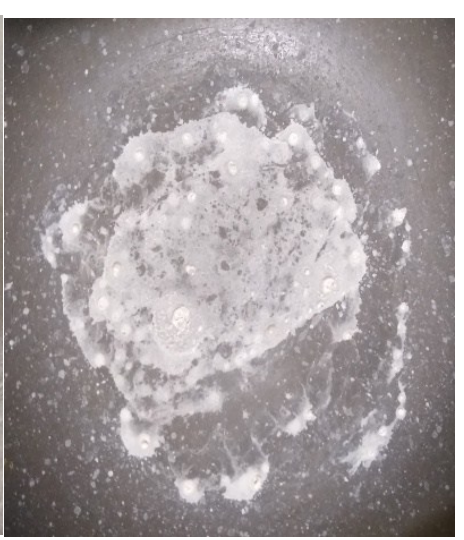

Fig 3: Gandhamliya Yashada Kshara Yashada Jala

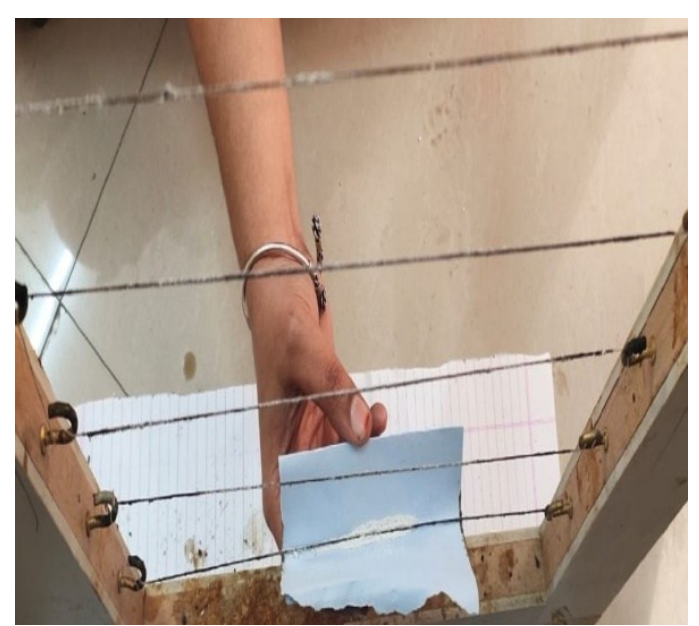

Fig 4: Gandhamliya Yashada Kshara coating

\section{ACKNOWLEDGEMENT}

The authors thank all faculties in the department of Shalya Tantra, Government Ayurvedic medical college, Bengaluru for their guidance, support in selecting the study and helping out in the preparation of Kshara sutra.

\section{REFERENCES}

1. Sushrutha Samhitha by Professor Kevala krishna takrala, Chaukamba Orientals, Varanasi, Sutra sthana 25/10.

2. Sushrutha Samhitha by Professor Kevala krishna takrala, Chaukamba Orientals, Varanasi. Chikitsa Sthana 17/29.

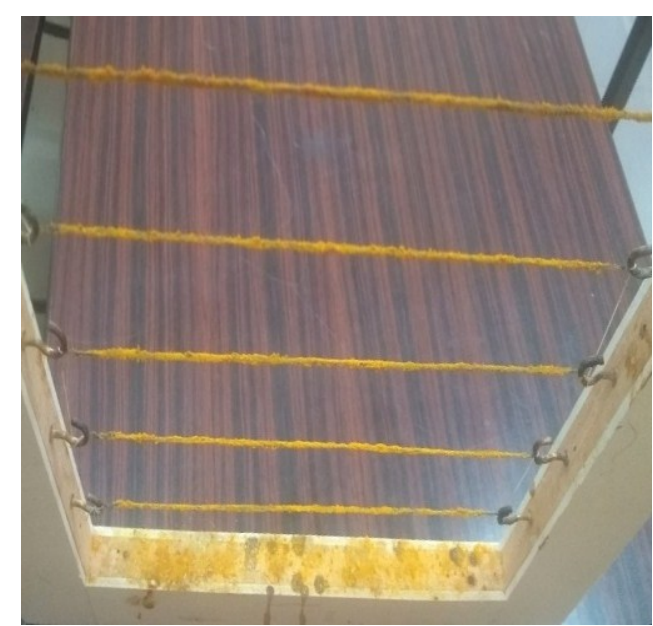

Fig 5: Gandhamliya Yashada Kshara sutra

3. Somen Das - A concise textbook of surgery $10^{\text {th }}$ edition, 2018.

4. RCG Russel N.S. Williams, CJK bulstroade, editors Bailey and Love's short practice of surgery $26^{\text {th }}$ edition London, Arnold a member of the Holder Headline group, 2000.

5. Somen Das - A concise textbook of surgery $10^{\text {th }}$ edition, 2018.

6. Pranacharya Shri Sadananda Sharma - Rasa Tarangini Hindi translation by Kasthuri Shastri, Motilal Banaras publication, Varanasi, 2000, 19/ 65.

7. Pranacharya Shri Sadananda Sharma - Rasa Tarangini hindi translation by Kasthuri Shastri, Motilal Banaras publication, Varanasi, 2000, 19/112 - 115. 
8. Pranacharya Shri Sadananda Sharma - Rasa Tarangini hindi translation by Kasthuri Shastri, Motilal Banaras publication, Varanasi, 2000, 19/149-152.

9. Bhavamishra - Bhavaprakasha Nigantu, commentary by professor K.C. Chunekar, edited by Late Dr. G.S. Pandey, Varanasi 2013, Chaukamba bharathi academy. Karpuradi varga, verse 32.

10. Pranacharya Shri Sadananda Sharma - Rasa Tarangini hindi translation by Kasthuri Shastri, Motilal Banaras publication, Varanasi, 2000, 19/153,154,155.

\section{Source of Support: Nil \\ Conflict of Interest: None Declared}

How to cite this URL: Keerthi Kumari B. R \& Shilpa P. N: A Conceptual Study on The Effect of Guggulu Based Gandhamliya Yashada Kshara Sutra In Shalyaja Nadi Vrana. International Ayurvedic Medical Journal \{online\} 2021 \{cited February, 2021\} Available from: http://www.iamj.in/posts/images/upload/400_404.pdf 